\title{
PREPARATION AND RECYCLING OF POLYMER ECO-COMPOSITES I. COMPARISON OF THE CONVENTIONAL MOLDING TECHNIQUES FOR PREPARATION OF POLYMER ECO-COMPOSITES
}

\author{
Vineta Srebrenkoska $^{1^{*}}$, Gordana Bogoeva Gaceva ${ }^{2}$, Dimko Dimeski ${ }^{1}$ \\ ${ }^{1}$ Faculty of Technology, Goce Delčev University, \\ "Krste Misirkov" b.b. P.O. Box 201, 2000 Štip, Republic of Macedonia \\ ${ }^{2}$ Faculty of Technology and Metallurgy, SS. Cyril \& Methodius University, \\ MK-1000 Skopje, Republic of Macedonia \\ vineta.srebrenkoska@ugd.edu.mk; dimko.dimeski@ugd.edu.mk; gordana@tmf.ukim.edu.mk
}

\begin{abstract}
The interest in natural fiber-reinforced polymer composites is growing rapidly due to their high performance in terms of mechanical properties, significant processing advantages, excellent chemical resistance, low cost and low density. In this study, the compression and injection molding of polypropylene (PP) and polylactic acid (PLA) based composites reinforced with rice hulls or kenaf fibers was carried out and their basic properties were examined. Rice hulls from rice processing plants and natural lignocellulosic kenaf fibers from the bast of the plant Hibiscus Cannabinus represent renewable sources that could be utilized for composites. Maleic anhydride grafted PP (MAPP) and maleic anhydride grafted PLA (MAPLA) were used as coupling agents (CA) to improve the compatibility and adhesion between the fibers and the matrix. Composites containing $30 \mathrm{wt} \%$ reinforcement were manufactured by compression and injection molding, and their mechanical and thermal properties were compared. It was found that the techniques applied for manufacturing of the eco-composites under certain processing conditions did not induce significant changes of the mechanical properties. The flexural strength of the compressed composite sample based on PP and kenaf is 51. $3 \mathrm{MPa}$ in comparison with 46.7 MPa for the same composite produced by injection molding technique. Particularly, PP-based composites were less sensitive to processing cycles than PLA-based composites. The experimental results suggest that the compression and injection molding are promising techniques for processing of eco-composites. Moreover, the PP-based composites and PLA-based composites can be processed by compression and injection molding. Both composites are suitable for applications as construction materials.
\end{abstract}

Key words: eco-composites; polypropylene; polylactic acid; rice hulls; kenaf fibers; compression molding; injection moulding

\section{ДОБИВАЊЕ И РЕЦИКЛИРАЊЕ НА ПОЛИМЕРНИ ЕКО-КОМПОЗИТИ І. СПОРЕДБА НА КОНВЕНЦИОНАЛНИТЕ ТЕХНОЛОГИИ ЗА ПРЕСУВАЊЕ ПРИМЕНЕТИ ЗА ПОДГОТОВКА НА ПОЛИМЕРНИ ЕКО-КОМПОЗИТИ}

\footnotetext{
Интересот за полимерните композити зајакнати со природни влакна расте брзо поради нивните добри механички својства, одличната хемиска отпорност, можноста за нивното процесирање, ниската цена и нискаta густина. Во овој труд беа процесирани по компресиона и инјекциона постапка композити на основа на полипропилен (PP) и полимлечна киселина (PLA) зајакнати со кенаф-влакна или оризови лушпи и беа испитувани нивните основни својства. Оризовите лушпи кои се добиваат со процесирање на оризот и кенафвлакната добиени од растението Hibiscus Cannabinus претставуваат обновливи извори кои можат да се искористат за композити. Како компатибилизирачки агенси за подобрување на атхезијата меѓу влакната и матрицата беа користени: калемен PP со малеински анхидрид (MAPP) и калемена PLA со малеински анхидрид (MAPLA). Композитите беа произведени со компресионо и инјекционо пресување и содржината на зајакнувачот во сите композити беше 30 \%мас. Беа испитувани и споредувани нивните механички и термички својства. Резултатите укажуваат дека применетите техники за производство на еко-композитите не влијаат многу на нивните механички карактеристики. На пример, јачината на свиткување на композит врз база на РP и кенаф-влакна добиен со компресионо пресување изнеува 51,3 MРа во споредба со 46,7 МРа за истиот
} 


\begin{abstract}
композит добиен со инјекционо пресување. Композитите врз база на РР се покажаа помалку осетливи на начинот на пресување во споредба со композитите врз база на PLA. Добиените експериментални резултати укажуваат на тоа дека компресионото и инјекционото пресување претставуваат технологии применливи за процесирање на еко-композитите. Композитите на основа на PР и PLA се покажаа соодветни за конвенционалните технологии за компресионо и инјекционо пресување. Овие композити можат да се применуваат како конструкциони материјали.
\end{abstract}

Клучни зборови: еко-композити; полипропилен; полимлечна киселина; оризови лушпи; кенаф-влакна; компресионо пресување; инјекционо пресување

\section{INTRODUCTION}

Public attention is now being placed on the environmentally gentle composite materials made from natural fibres and thermoplastics. The development of eco composite materials has accelerated rapidly, primarily due to improvements in process technology and economic factors $[1,2]$.

Natural fibers (NF) reinforced materials offer many environmental advantages, such as reduced dependence on non-renewable energy/material sources, lower pollution and greenhouse emission. Natural lignocellulosic fibers (flax, jute, hemp, etc.) represent an environmentally friendly alternative to conventional reinforcing fibers (glass, carbon). Advantages of natural fibers over traditional ones are their low cost, high toughness, low density, good specific strength properties, reduced tool wear (nonabrasive to processing equipment), enhanced energy recovery, $\mathrm{CO}_{2}$-neutrality when burned, and biodegradability. Due to their hollow and cellular nature, natural fibers perform well as acoustic and thermal insulators, and exhibit reduced bulk density. Depending of their performance, when they are embedded in the polymer matrix, lignocellulosic fibers can be classified into three categories: (1) wood flour particulates, which increase the tensile and flexural modulus of the composites, (2) fibers of higher length/diameter ratio that improve the composites modulus and strength when approriate additives are used to regulate the stress transfer between the matrix and the fibers, and (3) long natural fibers with the highest efficiency amongst the lignocellulosic reinforcements. The most efficient natural fibers have been considered those that have a high cellulose content coupled with a low microfibril angle, resulting in high filament mechanical properties $[3,4]$.

There are many different polymers from renewable sources: for example polylactic acid (PLA), cellulose esters, poly(hydroxyl butyrates), starch and lignin based polymer materials. Among these, PLA has the potential for use in electronic and construction applications because it can be fabricated with desired physical properties, such as heat resistance, mechanical response coupled with moldability, and recyclability. PLA is a degradable thermoplastic polymer with excellent mechanical properties and it is produced on a large scale by fermentation of corn starch to lactic acid and subsequent chemical polymerization. This polymer is characterized by its transparency, humidity and oil resistance. Pure PLA can degrade to carbon dioxide, water and methane in the environment over a period of several months to 2 years, compared to other petroleum plastics needing very longer periods $[5,6,7]$. The mechanical properties of PLA have been extensively studied as a biomaterial in the medicine, but only recently it has been used as a polymer matrix in eco-composites [8]. Its applications and use in eco-composites is still limited by its high price when compared with other biodegradable polymers. Xia et al. [9] investigated the use of PLA resin reinforced with kenaf fibers for the interior parts of its Prins hybrid car. In 2002 Cargill-Dow LLC started up a commercial polylactide plant, with the aim of production of PLA fibers for textiles and nonwovens, PLA film packaging applications, and rigid thermoformed PLA containers [10].

Amongst eco-compatible polymer composites, special attention has been given to polypropylene composites [11]. PP could not be classified as a biodegradable polymer, but PP takes an important place in eco-composite materials. For example, Mohanty et al. have demonstrated that the NF reinforced PP composites have potential to replace glass-PP composites [12]. It has also been reported that PP can be effectively modified by maleic anhydride, providing polar interactions and covalent bonds between the matrix and the hydroxyl groups of cellulose fibers [13]. Visteon and Technilin developed flax/PP materials, R-Flax ${ }^{\circledR}$ based on low cost fibers. Tech-Wood Interational from the Netherlands announced Tech-Wood ${ }^{\circledR}$ eco-composite, suitable for construction elements [14]. TechWood $\AA$ eco-composite material contains $70 \%$ pinewood fibers and $30 \%$ compatibilized PP. 
The purpose of this study was to compare the compression and injection molding techniques (which are usually applied for the production of conventional composites) for polymer eco-composites, with respect to their resulting properties. The injection moulding technique is the most common method of shaping polymer materials, and therefore it was of great practical interest to investigate its applicability for the production of eco-composites as well. The fillers/fibers were compounded with the matrix and the coupling agent by reactive blending, and the compounds were compressed and injection molded. The influence of the processing techniques on the properties of composites was evaluated through the mechanical and thermal characterization of the composites.

This work is a followup of the successfully finished ECO-PCCM project [15], in which ecocomposites based on PLA, PHBV and PP were prepared by molding techniques and investigated in order to obtain new eco-compatible construction panels and elements for eco-houses $[15,16]$.

\section{EXPERIMENTAL}

\subsection{Materials}

Isostatic PP, Moplen X30S, kindly supplied by Basell Polyolefins (Ferrara, Italy), and PLA, produced by Biomer, Krailling - Germany, were used as matrices. Rice hulls from agricultural waste were kindly supplied by Rice Institute from Kočani, Macedonia. Kenaf fibers, average length of $5.1 \mathrm{~mm}$ and average diameter of $21 \mu \mathrm{m}$, were kindly supplied by Kenaf Eco Fibers Italia S.p.A. (Guastall Italy). Before mixing, kenaf fibers $(\mathrm{K})$ and rice hulls $(\mathrm{RH})$ were vacuum-dried for $24 \mathrm{~h}$ to adjust their moisture content to 1-2 wt\%. Maleic anhydride-grafted PP (MAPP), KA 805 (Basell Polyolefins Ferrara, Italy), and maleic anhydridegrafted PLA (MAPLA) were used as coupling agents (CA) and they were added to PP and PLA during the reactive blending.

\subsection{Compounding of composite materials}

The composite compounds were prepared by melt mixing, in a Haake Rheocord 9000 batch mixer (New Jersey, USA). First, the polymer and coupling agent were mixed for $3 \mathrm{~min}$ at $185^{\circ} \mathrm{C}$ and $175^{\circ} \mathrm{C}$, respectively for PP and PLA based com- posites; then $30 \mathrm{wt} \%$ of fillers/fibers were added and the mixing proceeded for further $10 \mathrm{~min}$ at the same temperature. The mixing speed was progressively increased during mixing, up to $64 \mathrm{rpm}$ (3 min with a mixing speed of $8 \mathrm{rpm}$, then 4 min at $38 \mathrm{rpm}$, and finally $3 \mathrm{~min}$ at $64 \mathrm{rpm}$ ). The obtained composites were then cut into granules suitable for molding. The codes of the samples obtained are shown in Table 1.

Table 1

Codes of composite samples

\begin{tabular}{|c|c|c|c|c|c|c|}
\hline \multirow{2}{*}{ Codes } & \multicolumn{2}{|c|}{ Matrix } & \multicolumn{2}{|c|}{ Fiber/Filler } & \multicolumn{2}{|c|}{ Coupling agent (CA) } \\
\hline & Type & $\begin{array}{c}\text { Content } \\
(\mathrm{wt} \%)\end{array}$ & Type & $\begin{array}{c}\text { Content } \\
(\text { wt } \%)\end{array}$ & Type & $\begin{array}{c}\text { Content } \\
(w t \%)\end{array}$ \\
\hline $\mathrm{PP} / \mathrm{K} / \mathrm{CA}$ & PP & 65 & $\begin{array}{l}\text { Kenaf } \\
\text { fibers }\end{array}$ & 30 & MAPP & 5 \\
\hline $\mathrm{PP} / \mathrm{RH} / \mathrm{CA}$ & & & $\begin{array}{l}\text { Rice } \\
\text { Hulls }\end{array}$ & & & \\
\hline $\mathrm{PLA} / \mathrm{K} / \mathrm{CA}$ & PLA & 65 & $\begin{array}{l}\text { Kenaf } \\
\text { fibers }\end{array}$ & 30 & MAPLA & 5 \\
\hline $\mathrm{PLA} / \mathrm{RH} / \mathrm{CA}$ & & & $\begin{array}{l}\text { Rice } \\
\text { Hulls }\end{array}$ & & & \\
\hline
\end{tabular}

\subsection{Compression and injection molding}

The samples for mechanical testing were fabricated by compression and injection molding. The steps of the injection molding cycle will be described in details, since the processing parameters were chosen after several attempts of process optimization [17].

Compression molding. The pellets obtained after melt mixing of starting materials were placed into a molding frame with the desired dimensions and compression molded at $T=185{ }^{\circ} \mathrm{C}$ for PP based composites and $T=175{ }^{\circ} \mathrm{C}$ for PLA based composites, both for 10 minutes, with progressively increasing the pressure from 50 to 150 bar. The press was cooled using a cold water flow. Sheets with a thickness of about $5 \mathrm{~mm}$ were obtained.

Injection molding. The injection system consisted of a hopper, a reciprocating screw and barrel assembly, and an injection nozzle, as shown in Figure 1. This system confines and transports the plastic as it progresses through the feeding, compressing, degassing, melting, injection, and packing stages. 


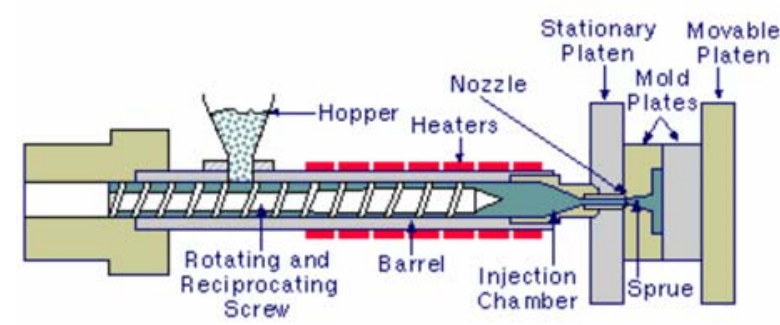

Fig. 1. A single screw injection molding machine for thermoplastics, showing the plasticizing screw, a barrel, band heaters to heat the barrel, a stationary platen, and a movable platen

The pellets obtained after melt mixing of starting materials, are supplied to the molders in the form of small pellets. The hopper on the injection molding machine holds these pellets. The pellets are gravity-fed from the hopper through the hopper throat into the barrel and screw assembly. As shown in Figure 1, the barrel of the injection molding machine supports the reciprocating plasticizing screw. It is heated by the electric heater bands. The reciprocating screw is used to compress, melt, and convey the material. The reciprocating screw consists of three zones (illustrated below in Figure 2):

- the feeding zone

- the compressing (or transition) zone

- the metering zone

While the outside diameter of the screw remains constant, the depth of the flights on the reciprocating screw decreases from the feed zone to the beginning of the metering zone. These flights compress the material against the inside diameter of the barrel, which creates viscous (shear) heat. This shear heat is mainly responsible for melting of the material. The heater bands outside the barrel help maintain the material in the molten state. Typically, a molding machine can have three or more heater bands or zones with different temperature settings.

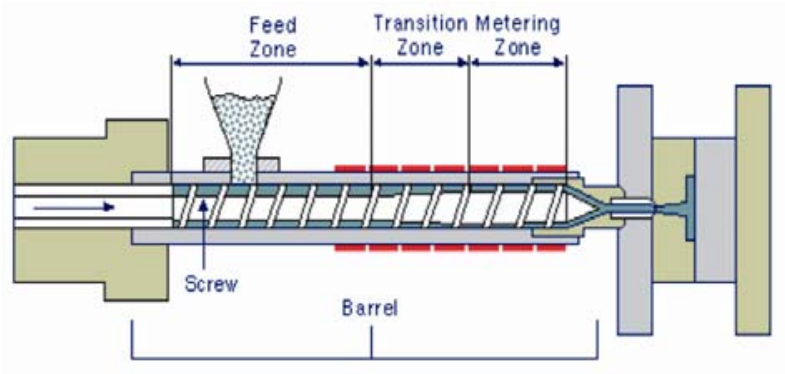

Fig. 2. A reciprocating screw, showing the feeding zone, compressing (or transition) zone, and metering zone
The nozzle connects the barrel to the sprue bushing of the mold and forms a seal between the barrel and the mold. The temperature of the nozzle should be set to the material's melt temperature or just below it, depending on the recommendation for the material used. When the barrel is in its full forward processing position, the radius of the nozzle should nest and seal in the concave radius in the sprue bushing with a locating ring. During purging of the barrel, the barrel backs out from the sprue, so the purging compound can free fall from the nozzle. These two barrel positions are illustrated below in Figure 3.

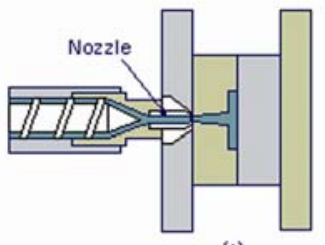

(a)

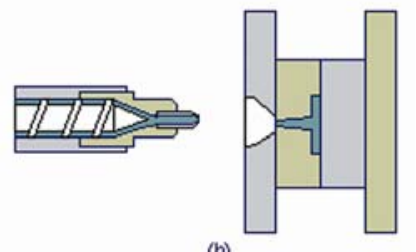

(b)
Fig. 3 (a) Nozzle with barrel in processing, (b) Nozzle with barrel blocked out for purging

Mold system. The mold system consists of tie bars, stationary and moving platens, as well as molding plates (bases) that house the cavity, sprue and runner systems, ejector pins, and cooling channels, as shown in Figure 4. The mold is essentially a heat exchanger in which the molten thermoplastic solidifies to the desired shape and dimensional details defined by the cavity.

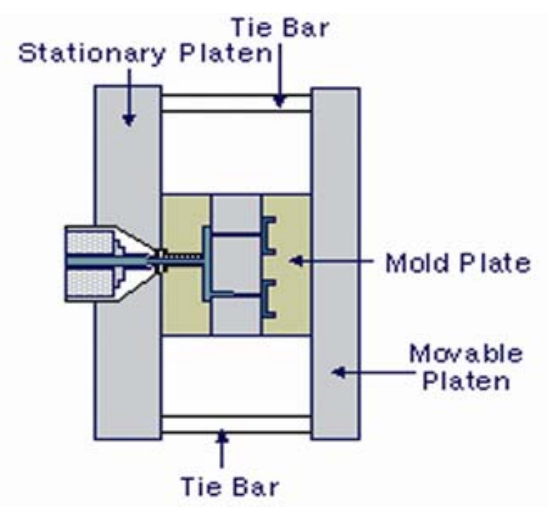

Fig. 4. A typical (three-plate) molding system

A mold system is an assembly of platens and molding plates typically made of tool steel. The mold system shapes the plastics inside the mold cavity (or matrix of cavities) and ejects the molded part(s). The stationary platen is attached to the barrel side of the machine and is connected to the 
moving platen by the tie bars. The cavity plate is mounted on the stationary platen and houses the injection nozzle. The core plate moves with the moving platen guided by the tie bars. Occasionally, the cavity plate is mounted to the moving platen and the core plate and a hydraulic knock-out (ejector) system is mounted to the stationary platen.

Cooling channels are passageways located within the body of a mold, through which a cool- ing medium (typically water, steam, or oil) circulates. Their function is the regulation of temperature on the mold surface. Cooling channels can also be combined with other temperature control devices, like bafflers, bubblers, and thermal pins or heat pipes.

The composite pellets were injection molded at temperature conditions as shown in Table 2 .

Table 2

Typical temperatures in the zones of the injection machine, ${ }^{\circ} \mathrm{C}$

\begin{tabular}{lcccc}
\hline \hline Composite samples & PP/K/CA & PP/RH/CA & PLA/K/CA & PLA/RH/CA \\
\hline Temperature in the hopper & $35-40$ & $35-40$ & $25-35$ & $25-35$ \\
Temperature in the feeding zone & $120-150$ & $120-150$ & $110-140$ & $110-140$ \\
Temperature in the in the compressing zone & $150-180$ & $150-180$ & $140-170$ & $140-170$ \\
Temperature in the metering zone & $185-195$ & $185-195$ & $170-185$ & $170-185$ \\
Temperature in the in the nozzle & $190-200$ & $190-200$ & $185-190$ & $185-190$ \\
\hline \hline
\end{tabular}

From each of the thermoplastic materials a representative sample part was produced (see Fig. 5) and its mechanical properties were tested.

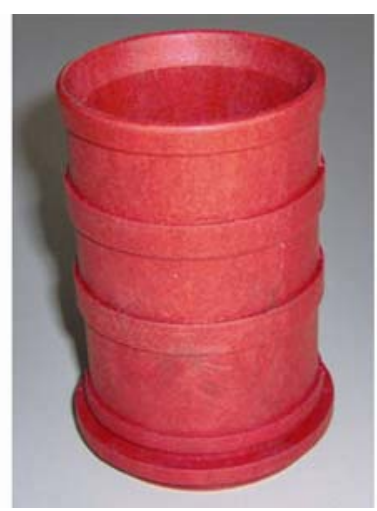

Fig. 5. Strength retention of injection molded composites compared to compression molded composites

\subsection{Methods}

The mechanical and thermal properties of the moldings such as impact resistance (Charpy impact test according ASTM D 256), compression strength (ASTM D 695), flexural strength and the modulus (ASTM D 790) were determined. For all mechanical tests, the universal testing machines (Schenk and Frank, Germany) were used.
The thermal stability of compression molded composite samples was measured using a Perkin Elmer Pyris Diamond Thermogravimetrical Analyzer (TGA). About $10 \mathrm{mg}$ of each sample was heated from $50^{\circ} \mathrm{C}$ to $600^{\circ} \mathrm{C}$ at heating rate of $20^{\circ} \mathrm{C} / \mathrm{min}$ under nitrogen flow $(25 \mathrm{~mL} / \mathrm{min})$.

\section{RESULTS AND DISCUSSION}

\subsection{Mechanical analysis}

PP and PLA based composites were prepared by a proper in situ reactive compatibilization. This preparation strategy involves addition of low amount of MAPP and MAPLA (reactive coupling agents) to the composite components. These coupling agents are constituted from PP and PLA segments (the same as the polymer matrices) and by MA groups grafted onto PP and PLA segments, which become reactive with respect to the hydroxyl groups present on the reinforcement surface. In this way, physical and/or chemical interactions between hydroxyl and maleic anhydride groups, generated during the mixing, are responsible for the in situ formed grafted species that can act as effective compatibilizers for the PP and PLA/natural reinforcements composites $[18,19]$. 
In order to evaluate the response of the composites to the molding techniques in terms of their mechanical properties, the materials were successively processed as described in the experimental session.

The physical and mechanical properties of compression molded and injection molded composites are summarized in Table 3 and Table 4, re- spectively. It should be mentioned, that, prior to this investigation, the optimization of compression and injection molding processes was already been performed, as reported in our earlier work [20,21]. As it can be seen from the results, the composites reinforced with kenaf fibers show higher modulus and strength than the composites reinforced with rice hulls.

Table 3

The physical and mechanical properties of the composites produced by compression molding

\begin{tabular}{l|c|cccc}
\hline \hline \multirow{2}{*}{ Characteristics } & \multirow{2}{*}{ Unit } & \multicolumn{4}{|c}{ Composite } \\
\cline { 3 - 5 } & & PP/K/CA & PP/RH/CA & PLA/K/CA & PLA/RH/CA \\
\hline Flexural strength & $\mathrm{MPa}$ & $51.3 \pm 4.84$ & $42.6 \pm 3.45$ & $46.7 \pm 3.83$ & $28.8 \pm 3.14$ \\
Flexural modulus & $\mathrm{GPa}$ & $2.11 \pm 0.07$ & $1.94 \pm 0.08$ & $2.05 \pm 0.11$ & $1,63 \pm 0.09$ \\
Impact strength & $\mathrm{kJ} / \mathrm{m}^{2}$ & $71.4 \pm 4.67$ & $69,2 \pm 3.83$ & $54.3 \pm 3.49$ & $48,7 \pm 4.16$ \\
Compression strength & $\mathrm{MPa}$ & $47.2 \pm 2.93$ & $36.3 \pm 2.39$ & $34,5 \pm 3.11$ & $21,6 \pm 2.67$ \\
Compression modulus & $\mathrm{GPa}$ & $1.86 \pm 0.12$ & $1,58 \pm 0.09$ & $1,74 \pm 0.11$ & $1,46 \pm 0.07$ \\
Tensile strength & $\mathrm{MPa}$ & $29.6 \pm 3.84$ & $22.7 \pm 4.82$ & $28.3 \pm 6,54$ & $26.7 \pm 1,49$ \\
Tensile modulus & $\mathrm{GPa}$ & $1.65 \pm 0,025$ & $1.78 \pm 0,014$ & $2.87 \pm 0.23$ & $2.76 \pm 0.11$ \\
\hline \hline
\end{tabular}

Table 4

The mechanical properties of the injection molded composite samples

\begin{tabular}{lccccc}
\hline \hline \multirow{2}{*}{ Characteristics } & \multirow{2}{*}{ Unit } & \multicolumn{4}{c}{ Composite } \\
\cline { 3 - 6 } & & $\mathrm{PP} / \mathrm{K} / \mathrm{CA}$ & $\mathrm{PP} / \mathrm{RH} / \mathrm{CA}$ & $\mathrm{PLA} / \mathrm{K} / \mathrm{CA}$ & PLA/RH/CA \\
\hline Flexural strength & $\mathrm{MPa}$ & $40.1 \pm 4.82$ & $32.8 \pm 3.44$ & $34.1 \pm 3.75$ & $20,7 \pm 2.82$ \\
Impact strength normal to the axis & $\mathrm{kJ} / \mathrm{m}^{2}$ & $57.1 \pm 4.76$ & $55.0 \pm 4.13$ & $40.7 \pm 3.86$ & $36.1 \pm 3.46$ \\
Compression strength parallel to the axis & $\mathrm{MPa}$ & $38.2 \pm 2.93$ & $28.1 \pm 2.43$ & $26.5 \pm 2.51$ & $15.8 \pm 1.91$ \\
Compression strength normal to the axis & $\mathrm{GPa}$ & $27.8 \pm 2.27$ & $23.5 \pm 2.44$ & $22.6 \pm 2.01$ & $13.6 \pm 1.83$ \\
Tensile strength & $\mathrm{MPa}$ & $23.6 \pm 2.14$ & $17.9 \pm 1.24$ & $21.8 \pm 1.02$ & $20.6 \pm 0.91$ \\
\hline \hline
\end{tabular}

The flexural, impact, compression and tensile strengths of the injection molded composite samples,decrease for about $25 \%$ as a result of the applied molding technique, when compared to the compression molded ones. For injection molded composites based on PP, the applied molding technique induces a lower decrease of the strengths when compared to the composites based on PLA. The effect of the injection molding technique on the property retention of the obtained composite samples in comparison to the compression molded ones (in percentage), is illustrated in Fig. 6.

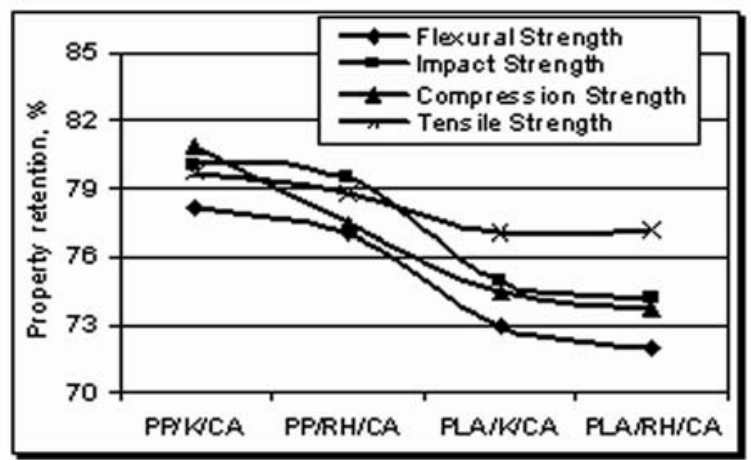

Fig. 6. Injection molded inlet tube for "Tomos" water pump based on Kenaf/PLA 
Table 5

Comparison of flexural properties of commercially available formaldehyde-based wood composites [22] and compatibilized PP/Kenaf, PP/Rice hulls, PLA/Kenaf and PLA/Rice hulls composites produced by compression molding

\begin{tabular}{|c|c|c|c|c|}
\hline \multirow{2}{*}{ Sample } & \multicolumn{2}{|c|}{$\begin{array}{l}\text { Flexural strength range } \\
\qquad(\mathrm{MPa})\end{array}$} & \multicolumn{2}{|c|}{$\begin{array}{l}\text { Flexural modulus range } \\
\qquad(\mathrm{GPa})\end{array}$} \\
\hline & low & high & low & high \\
\hline High-density fiberboards [22] (commercial) & 38 & 69 & 4.48 & 7.58 \\
\hline Medium-density fiberboards [22] (commercial) & 13.1 & 41.4 & 2.24 & 4.83 \\
\hline PP/Rice hulls/CA ${ }^{b}$ & \multicolumn{2}{|c|}{$42.6(3.4)^{a}$} & \multicolumn{2}{|c|}{$1.94(0,08)^{a}$} \\
\hline $\mathrm{PP} /$ Kenaf $/ \mathrm{CA}^{b}$ & \multicolumn{2}{|c|}{$51.3(4.8)^{a}$} & \multicolumn{2}{|c|}{$2.11(0.07)^{a}$} \\
\hline PLA/Rice hulls/CA ${ }^{b}$ & \multicolumn{2}{|c|}{$28.8(3.1)^{a}$} & \multicolumn{2}{|c|}{$1.63(0.09)^{a}$} \\
\hline $\mathrm{PLA} / \mathrm{Kenaf} / \mathrm{CA}^{b}$ & \multicolumn{2}{|c|}{$46.7(3.8)^{a}$} & \multicolumn{2}{|c|}{$2.05(0.11)^{a}$} \\
\hline
\end{tabular}

${ }^{a}$ Standard deviations are in brackets for the PP/kenaf, PP/rice hull, PLA/kenaf and PLA/rice hull composites ${ }^{b} \mathrm{CA}$ : coupling agent

Sanadi et al. [22] have studied the possibility of using highly filled agro-based fiber thermoplastic composites for furniture, automotive and building applications. They have shown that the performances of thermoplastic based composites are better than most of wood particle, low and medium density fiberboards. For our systems, a comparison of flexural properties of commercially available formaldehyde-based wood composites [22] and 30\% filled PP/kenaf and PP/rice hulls compressed composites is given in Table 5. The investigated compressed composites show flexural properties comparable to conventional formaldehyde-based fiberboards. But, the differences in the mechanical properties for the composites fabricated by injection molding using kenaf and jute fibers with polypropylene are smaller than that of compressed composite samples because of the applied fabrication technique [23].

\subsection{Thermogravimetric analysis}

Thermogravimetric (TGA) curves and derivate thermograms (DTG) for $\mathrm{PP} / \mathrm{RH} / \mathrm{CA}$ and $\mathrm{PP} / \mathrm{K} / \mathrm{CA}$ composites are shown in Fig.7, whereas TGA results are summarized in Table 6.

As it can be observed, thermal degradation of $\mathrm{PP} / \mathrm{RH} / \mathrm{CA}$ composite indicates a single stage process; maximum weight loss rates were observed at $424.5^{\circ} \mathrm{C}$ for $\mathrm{PP} / \mathrm{RH} / \mathrm{CA}$. A small shoulder can be noticed at approximately $350^{\circ} \mathrm{C}$, corresponding to the beginning of the thermal degradation of rice hulls. Even though the degradation process occurs in a single step, it can be considered an overlap of degradation phenomena associated with the different composite components. Lignocellulosic materials decompose thermochemically between $150^{\circ} \mathrm{C}$ and $500^{\circ} \mathrm{C}$ : hemicellulose, mainly between 150 and $350^{\circ} \mathrm{C}$, cellulose between 275 and $350^{\circ} \mathrm{C}$, and lignin between 250 and $500^{\circ} \mathrm{C}$ as reported by $\mathrm{Kim}$ et al. [24]. The residue at about $550^{\circ} \mathrm{C}$ corresponds to the amount of silica (approximately $10 \mathrm{wt} \%$ ) in the rice hulls, as determined in our earlier work, by TGA [25]. Ash in the rice hulls is mainly constituted by silica ( $\sim 96 \mathrm{wt} \%$ ), and the amount and distribution of silica in the rice hulls is likely to be an important factor in determining the properties of the composite products [24].

Table 6

Degradation temperature of composites determined by TGA at residual weight $90 \%\left(T d_{90}\right), 50 \%\left(T d_{50}\right)$, and $10 \%\left(T d_{10}\right)$

\begin{tabular}{llll}
\hline \hline Sample & $\begin{array}{l}\mathrm{Td}_{90} \\
\left({ }^{\circ} \mathrm{C}\right)\end{array}$ & $\begin{array}{l}\mathrm{Td}_{50} \\
\left({ }^{\circ} \mathrm{C}\right)\end{array}$ & $\begin{array}{l}\mathrm{Td}_{10} \\
\left({ }^{\circ} \mathrm{C}\right)\end{array}$ \\
\hline $\mathrm{PP} / \mathrm{RH} / \mathrm{CA}$ & 344.4 & 411.2 & 452.2 \\
$\mathrm{PP} / \mathrm{K} / \mathrm{CA}$ & 340.6 & 408.9 & 442.0 \\
\hline \hline
\end{tabular}




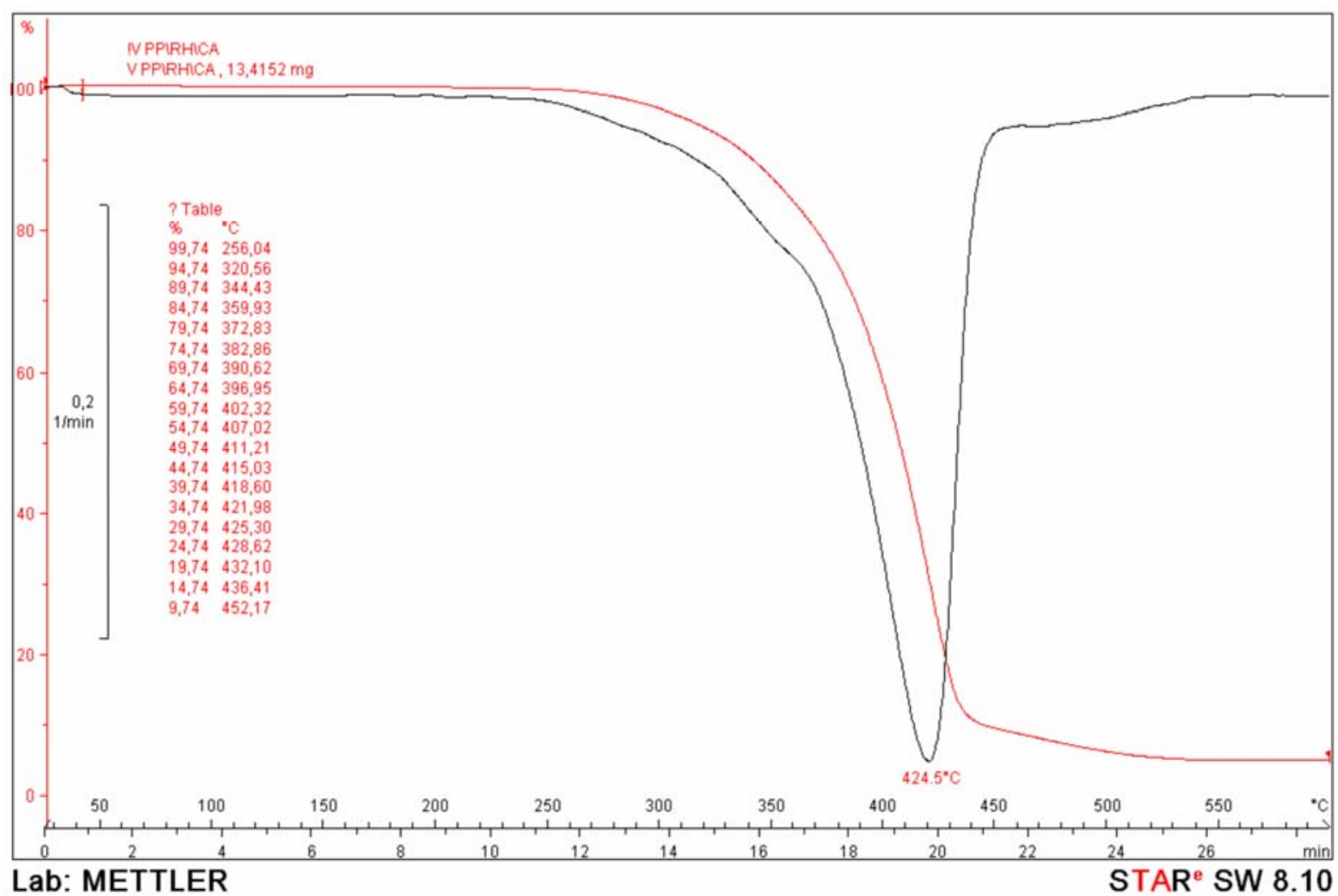

Fig. 7a. Weight loss and weight loss rate curves of PP/RH/CA

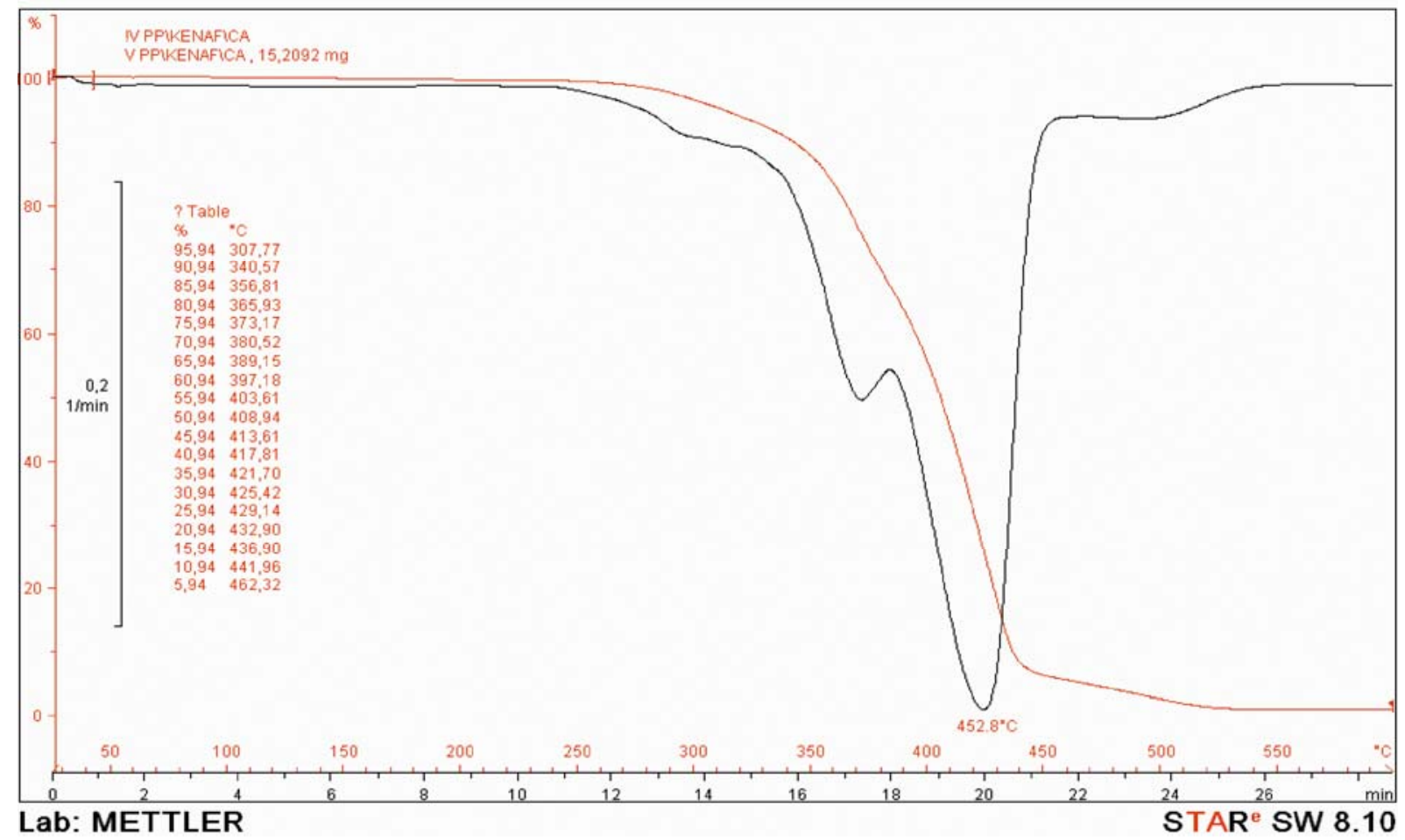

Fig. 7b. Weight loss and weight loss rate curves of PP/K/CA 
In the case of PP/Kenaf composites a twostage weight loss process was observed. The first stage, occurring in the temperature range from $350^{\circ} \mathrm{C}$ to $400^{\circ} \mathrm{C}$, is correlated to the degradation of low molecular weight components, such as hemicelluloses and cellulose, corresponding to thermal degradation of kenaf [26].

Results from the thermogravimetric analyse of PLA, rice hulls and their composite PLA/RH/CA $(65 / 30 / 5$ wt. \%) are presented in figure 8 (a) and table 7. PLA gradually losses $10 \%$ of its weight untill $350{ }^{\circ} \mathrm{C}$, and afterward suffers almost complete weight loss in a temperature interval from $350{ }^{\circ} \mathrm{C}$ untill $400{ }^{\circ} \mathrm{C}$. PLA based composite PLA/RH/CA (65/30/5wt.\%) lose $10 \%$ of its weight untill $300{ }^{\circ} \mathrm{C}$, followed by ongoing $75 \%$ weight loss untill $360-365{ }^{\circ} \mathrm{C}$, after that, weight loss continues with slower degradation rate. It should be noted that at temperature of $600{ }^{\circ} \mathrm{C}$ rice hulls exhibit high residual weight of $39.7 \%$. These find- ings are in accordance with the finding of Lee et al. [27] that thermal stability of PLA/bamboo fibre composites is lower than thermal stability of neat PLA matrix.

Derivative thermogravimetric curves for neat PLA, rice hulls and their composite PLA/RH/CA are presented in Figure $8 \mathrm{~b}$. Maximum weight loss rate for PLA $\left(3.37 \% /{ }^{\circ} \mathrm{C}\right)$ is reached at $362.9{ }^{\circ} \mathrm{C}$, and for rice hulls weight loss rate is uppermost $\left(0.72 \% /{ }^{\circ} \mathrm{C}\right)$ at $342.1{ }^{\circ} \mathrm{C}$. Composite PLA/RH/CA exhibits maximum weight loss rate of $1.93 \% /{ }^{\circ} \mathrm{C}$ at $343.2{ }^{\circ} \mathrm{C}$, a temperature almost $20{ }^{\circ} \mathrm{C}$ lower than the corresponding one for neat PLA, confirming again the previous finding for composites with lower thermal stability.

Shown in Table 8 are the degradation temperature values $(T d)$ calculated as the maximum of the degradation rate, and the residual weight at $500{ }^{\circ} \mathrm{C}$.

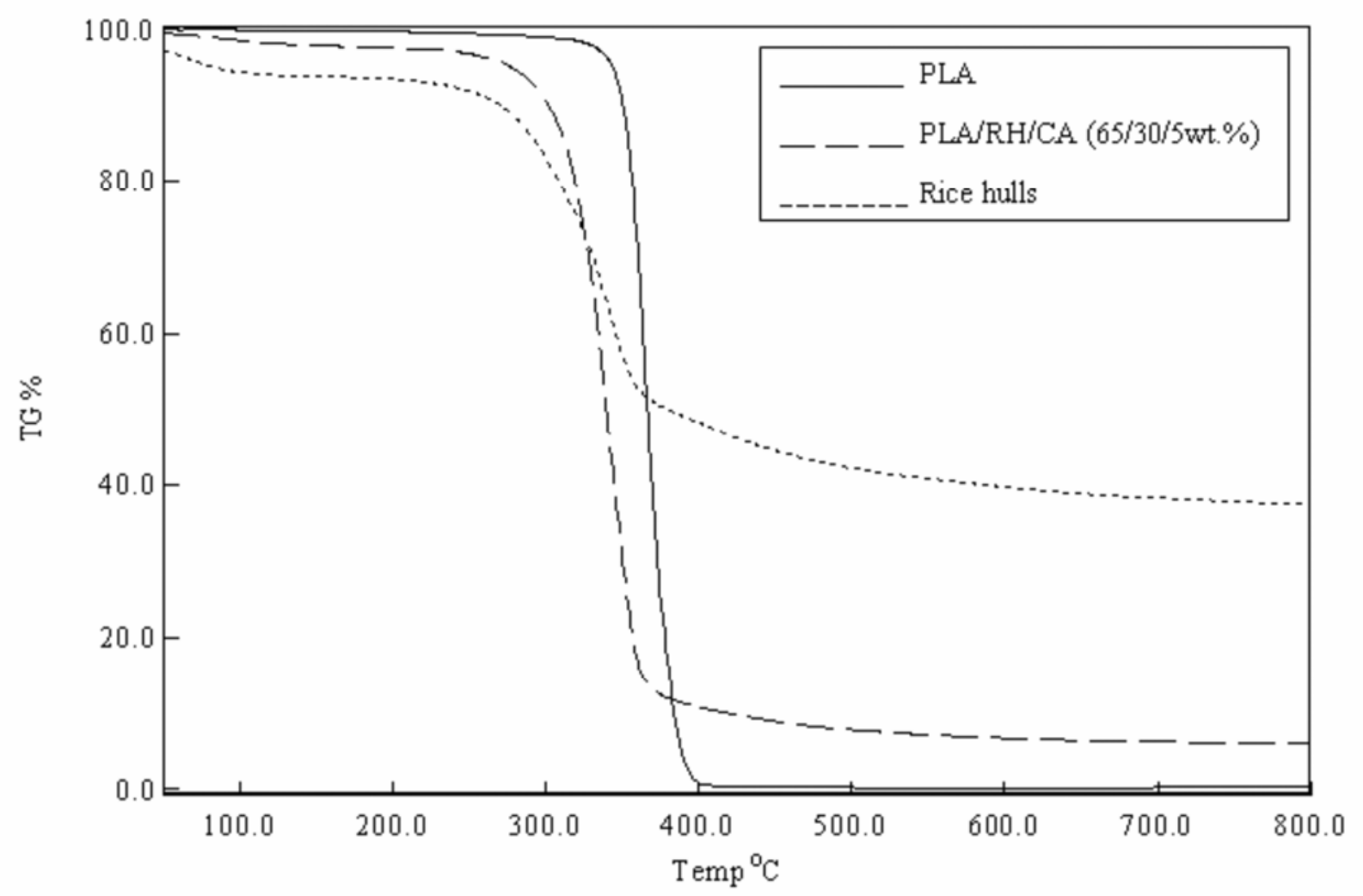

Fig. 8a. Thermogravimetric curves, weight loss (TG) versus temperature 


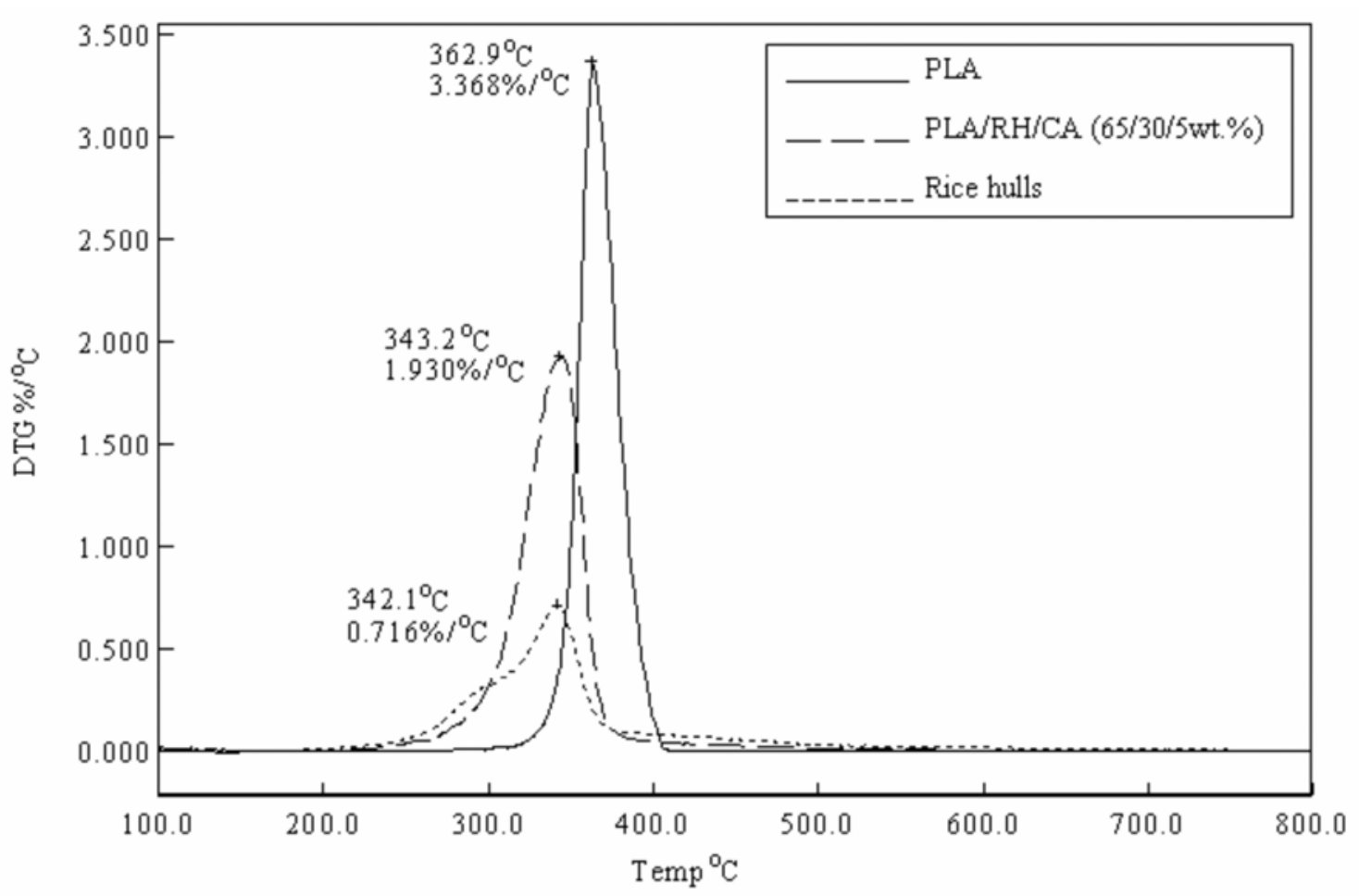

Fig. 8b. Derivative thermogravimetric curves, derivative weight loss (DTG) versus temperature

Table 7

Thermal stability of PLA, rice hulls and composite PLA/RH/CA (65/30/5wt. \%)

\begin{tabular}{cccc}
\hline \hline \multirow{3}{*}{$T\left({ }^{\circ} \mathrm{C}\right)$} & \multicolumn{3}{c}{ Weight loss $(\%)$} \\
\cline { 2 - 3 } & Rise hulls & PLA/RH/CA & Neat PLA \\
\hline 50 & 2.7 & 0.5 & 0 \\
100 & 5.6 & 1.4 & 0 \\
250 & 8 & 3.2 & 0.5 \\
290 & 14 & 6.9 & 0.9 \\
310 & 20.6 & 13.7 & 1.2 \\
330 & 29.7 & 33.5 & 2.1 \\
350 & 43 & 69.8 & 9.5 \\
370 & 49.1 & 86.9 & 61.3 \\
390 & 51 & 88.7 & 95.7 \\
410 & 52.6 & 89.7 & 99.6 \\
600 & 60.3 & 93.3 & 100 \\
\hline \hline
\end{tabular}

Table 8

Degradation temperature (Td) and residual weight at $500{ }^{\circ} \mathrm{C}$ of neat PLA and PLA based composite

\begin{tabular}{lcc}
\hline \hline Codes & $\begin{array}{c}T d \\
\left({ }^{\circ} \mathrm{C}\right)\end{array}$ & $\begin{array}{c}\text { Residual weight at } \\
500{ }^{\circ} \mathrm{C}(\%)\end{array}$ \\
\hline Neat PLA & 365 & 0.9 \\
Kenaf fibers & 348 & 17.2 \\
PLA/K/CA (65/30/5wt. \%) & 351 & 7.2 \\
\hline \hline
\end{tabular}

The thermal degradation for $\mathrm{PLA} / \mathrm{K} / \mathrm{CA}$ composite occurs in a single step; the maximum rate for this overall degradation process is about $352{ }^{\circ} \mathrm{C}$. It can be noted that kenaf fibers show very high residual weight at $500{ }^{\circ} \mathrm{C}$, about $17 \%$, which is in agreement with data reported in reference [26].

\section{CONCLUSION}

Based on the obtained results of the effect of applied techniques for manufacture of ecocomposites on their mechanical properties, the following conclusions can be drawn.

The mechanical properties of composites obtained by injection molding are very close to those obtained by compression molding. In particular, composites containing 30wt $\%$ of kenaf fibers and $5 \mathrm{wt} \%$ of coupling agent showed better mechanical properties than composites reinforced with rice hulls. Moreover, PP/kenaf and PLA/kenaf composites seem to be less sensitive to processing technique than $\mathrm{PP} / \mathrm{RH}$ and $\mathrm{PLA} / \mathrm{RH}$ composites. Thermal stability of the PP-based composites is slightly higher as compared to the PLA ones. For all composites complete weight loss were observed at temperature interval from $400{ }^{\circ} \mathrm{C}$ to $460{ }^{\circ} \mathrm{C}$. Both the PP- and PLA-based composites, espe- 
cially those reinforced with kenaf fibers, represent a good potential for processing by conventional molding techniques. Moreover, the obtained results for mechanical properties of composite samples, either processed by compression or injection molding, are comparable to those of conventional formaldehyde wood medium density fiberboards used as construction elements for indoor applications.

Acknowledgments. This work is a follow-up of successfully finished ECO-PCCM project which was financially supported by EU FP6-INCO-WBC program (INCO-CT-2004-509185). The production and characterization of the compressed polymer eco-composite were carried out in "11 Oktomvri-Eurokompozit" Prilep, Macedonia. Injection molded composites were produced in "Kanonada" - Prilep, Macedonia. The properties of the composites produced by injection molding technique were done in "Hyundai", Bulgaria, and in "11 Oktomvri--Eurokompozit" - Prilep, Macedonia. Thermal analysis was performed at the Institute of Chemistry and Technology on Polymers-ICTP-CNR, Italy. The authors are very grateful to all these institutions for their support in fulfilment of this research.

\section{REFERENCES}

[1] Y. Chen, L. S. Chiparus, I. Negulescu, D. V. Parikh, T.A. Calamari, Natural Fibers for Automotive Nonwoven composites, J. of Ind. Text. 35, 1, 47-61 (2005).

[2] K. P. Mieck, A. Nechwatal, C. Knobeldorf, Potential applications of natural fibres in composite materials, $\mathrm{Mel}$ liand Textilberichte 11, 228-30 (1994).

[3] Seung-Hwan Lee, Siqun Wang, Biodegradable polymers/bamboo fiber biocomposite with bio-based coupling agent, Composites: Part A 37, 80-91 (2006).

[4] K. Oksman, High quality flax fibre composites manufactured by the resin transfer moulding process, Journal of Reinforced Plastics and Composites 20(7), 621 (2001).

[5] K. Oksman, M. Skrifvars and J. F. Selin, Natural fibers as reinforcement in polylactic acid (PLA) composites, Composites Science and Technology 63, 1317-1324 (2003).

[6] R. Heijenrath, T. Peijs, Natural-fibre-mat-reinforced thermoplastic composites based on flax fibers and polypropylene, Advanced Composites Letters 5(3), 81-85 (1996).

[7] K. Oksman, Mechanical properties of natural fibre mat reinforced thermoplastics, Appl. Comp. Mat. 7, 403-14 (2000).

[8] S. Serizawa, K. Inoue, M. Iji, Kenaf-fiber-reinforced poly(lactic acid) used for electronic products, Journal of Applied Polymer Science, 100, 618-624 (2006).

[9] Z. Xia, W. A. Curtin, and T.Okabe: Compos. Sci. Technol. 62, 1279 (2002).

[10] http://www.cargilldow.com This is the official web site of the Cargill Dow LLC, 2005.
[11] H. S. Yang, D. J. Kim, J. K. Lee, H. J. Kim, J. Y. Jeon and C. W. Kang, Possibility of using waste tire composites reinforced with rice hulls as construction materials, Bioresource Technol. 95, 61-65 (2004b).

[12] A. K. Mohanty, L. T. Drzal, and M. Misra, J. Adhes. Sci. Technol. 16, 999 (2002).

[13] T. J. Keener, R. K. Stuart, and T. K. Brown, Compos. A 35, 357 (2004).

[14] A. N. Netravali and S. Chabba, Mater. Today 6 (4), 22 (2003).

[15] ECO-PCCM, FP6-INCO-CT-2004-509185.

[16] G. Bogoeva-Gaceva, A. Grozdanov, and A. Buzarovska, Eco-friendly polymer composites based on polypropylene and kenaf fibers, Proceedings of $3 \mathrm{rd}$ International Conference on Eco Composites, Royal Institute of Technology, Stockholm, Sweden, June 20-21, 2005.

[17] Pradoh C. Bolur, A guide to injection molding of plastics, $2^{\text {nd }}$ edition, SCI-TECH Books and Periodicals, Mumbai, 2005, p. 32.

[18] G. Bogoeva-Gaceva, A. Grozdanov, A. Buzarovska, Nonisothermal crystallization of maleic anhydride grafted PP: comparison of different kinetic models, Proceedings of 5th International Conference of the Chemical Societes of South-East European countries ICOSECS-5, September 10-14, Ohrid, Macedonia, 2006, pp.619.

[19] G. Bogoeva-Gaceva, A. Grozdanov, B. Dimzoski, Analysis of the reaction of modified polypropylene in melt, Proceedings of European Polymer Congress EPF, July 2-6, Portoroz, 2007.

[20] M. Avella, G. Bogoeva-Gaceva, A. Buzarovska, M. E. Errico, G. Gentile, A. Grozdanov, Poly(lactic acid)-based biocomposites reinforced with kenaf fibers, J. Appl. Poly. Sci. 108, 3542-3551 (2008).

[21] B. Dimzoski, G. Bogoeva-Gaceva, G. Gentile, M. Avella, M. E. Errico, V. Srebrenkoska, Preparation and characterization of poly(lactic acid)/rice hulls based biodegradable composites, J. Polym. Eng. 28, 369-384 (2008).

[22] A. R. Sanadi, J. F. Hunt, D. F. Caulfield, G. Kovacsvologyi, and B. Destree, High fiber-low matrix composites: kenaf fiber/polypropylene, Proceedings of 6th International Conference on Woodfiber-Plastic Composites, Madison, Wisconsin, May 15-16, 2001.

[23] D. V. Rossato, Handbook of Injection Molding, $3^{\text {rd }}$ edition, Kluwer Academic Publishers, 2000, pp. 24.

[24] H. S. Kim, H. S. Yang, H. J. Kim, H. J. Park, Thermogravimetric analysis of rice husk flour filled thermoplastic polymer composites, J. Therm. Anal. Calorim. 76, 395404 (2004).

[25] A. Grozdanov, A. Buzarovska, G. Bogoeva-Gaceva, M. Avella, M. E. Errico and G. Gentille, Rice hulls as an alternative reinforcement in polypropylene composites, Agron. Sustain. Dev. 26, 251-255 (2006).

[26] A. R. Sanadi, D. F. Caulfield, R. E. Jacobson, and R. M. Rowell, Renewable agricultural fibers as reinforcing fillers in plastics: Mechanical properties of kenaf fiberpolypropylene composites, Indust. Eng. Chem. Res. 34, 1889-1896 (1995).

[27] S. H. Lee, S. Wang, Composites Part A 37, 80-91 (2006). 